\title{
The J-GRID as a new player of networking
}

\author{
Yoshiyuki Nagai $^{1,2^{*}}$, Yoshiko Okamoto ${ }^{1}$ \\ From Institut Pasteur International Network Annual Scientific Meeting \\ Hong Kong. 22-23 November 2010
}

Infectious diseases heed no national borders. In order to enhance international research collaboration, the government of Japan launched a program in 2005, which is now named the Japan Initiative for Global Research Network on Infectious Diseases (J-GRID). This program includes establishing collaborative research centers in Asian and African countries on a reciprocal basis between Japanese universities/institutions and overseas partner universities/ institutions and setting up its headquarters CRNID at RIKEN to connect those bilateral collaboration centers into a network, the J-GRID. The J-GRID now consists of 12 collaboration centers in 8 countries (6 in Asia and 2 in Africa). Here, we describe the mission of J-GRID and some of its research results just coming out. However, the J-GRID is still in its infancy and needs a great deal of effort to maximize its research capacity and to ensure its sustainability. J-GRID is eager to learn a lot from Institut Pasteur Network and other international networks that are proud of long history, high quality research and great contribution to the global public health. What a single network is able to cover is limited. In view of the geographical complementarities, particularly in Asia, close collaboration between different networks (networking of networks) will certainly give rise to a profound synergistic effect.

\section{Author details}

'RIKEN Center of Research Network for Infectious Diseases (CRNID), Tokyo 101-0051, Japan. ${ }^{2} J a p a n$ Science and Technology Agency (JST),

Saitama 332-0012, Japan.

Published: 10 January 2011

doi:10.1186/1753-6561-5-S1-010

Cite this article as: Nagai and Okamoto: The J-GRID as a new player of

networking. BMC Proceedings 2011 5(Suppl 1):010.

'RIKEN Center of Research Network for Infectious Diseases (CRNID), Tokyo 101-0051, Japan

Full list of author information is available at the end of the article

Submit your next manuscript to BioMed Central and take full advantage of:

- Convenient online submission

- Thorough peer review

- No space constraints or color figure charges

- Immediate publication on acceptance

- Inclusion in PubMed, CAS, Scopus and Google Scholar

- Research which is freely available for redistribution

\section{() Biomed Central}

C Biomed Central

(c) 2011 Nagai and Okamoto; licensee BioMed Central Ltd. This is an open access article distributed under the terms of the Creative Commons Attribution License (http://creativecommons.org/licenses/by/2.0), which permits unrestricted use, distribution, and reproduction in any medium, provided the original work is properly cited. 